\title{
Estimates of the High-Employment Budget: 1947-1967
}

T

AXING AND SPENDING actions of the Federal Government are generally believed to have a significant effect on spending, production, employment, and prices. Among the various measures of Government fiscal actions, the high-employment budget is one of the best single measures of the net effect of these actions on economic activity.

The high-employment budget is an estimate of the national income accounts budget at some arbitrarily defined high-employment level of economic activity. ${ }^{1}$ Like other major budget measures, the high-employment budget is a statistical summary of Government spending and taxing activities. ${ }^{2}$ Its purpose is somewhat different, however. As a tool of economic analysis, the primary purpose of the high-employment budget is to serve as a measure of fiscal actions and to assist in the planning and formulation of stabilization policy.

The concept of a high-employment budget originated in the mid-1940's but its most recent emphasis dates from the 1962 Annual Report of the Council

1 Probably the most comprehensive discussion of the high-employment budget, including both theoretical and statistical aspects, is found in Michael E. Levy, Fiscal Policy, Cycles and Growth, National Industrial Conference Board, Studies in Business Economics, Number 81 (New York: The Conference Board, 1963). For an article stressing the use and interpretation of the high-employment budget concept, see Robert Solomon, "A Note on the Full Employment Budget Surplus,"

Review of Economics and Statistics, XLVI (February, 1964), 105-108. For a description of techniques and procedures for calculating high-employment budget estimates, much of which is repeated here, see Nancy H. Teeters, "Estimates of the Full-Employment Surplus, 1955 1964," Review of Economics and Statistics, XLVII (August, 1965), 309-321. Another article providing alternate estimates of the high-employment budget, along with an analysis of the appropriateness of budget policy, is Edward M. Gramlich, "The Behavior and Adequacy of the

United States Federal Budget, 1952-1964," Yale Economic

Essays, vol, 6 (Spring, 1966), pp. 99-159.

${ }^{2}$ Reference is made to the administrative, cash. and national income accounts budgets. For a summary of the relations among these budget measures, see the February 1967 issue of this Review, pp. 11-12. of Economic Advisers. ${ }^{3}$ Originally the high-employment budget was developed in terms of a target for Government fiscal operations, i.e., it was suggested that budget policy be formulated in such a way as to produce a balanced national income accounts budget at high employment. More recently, the high-employment budget concept has served as a general tool of economic analysis, providing (1) a measure of fiscal action, and (2) a measure of the impact of the budget on the economy. ${ }^{4}$

The purpose of this article is to present quarterly estimates of the high-employment budget for the period 1947 through early 1967 . Estimation procedures are summarized, and the reliability, meaning, and economic significance of the high-employment budget concept are discussed.

The estimation procedure is essentially the same as that developed by the Council of Economic Advisers. ${ }^{5}$ Their figures were last published in April 1966, and covered the period from the third quarter of 1955 to the

3 This was the first Annual Report by the Council which assumed duties in January 1961. The views of this Council, whose members were Walter Heller, Kermit Gordon, and James Tobin, were first printed in the Hearings on the January 1061 Economic Report of the President and the Economic Situation and Outlook (Washington: U.S. Government Printing Office, 1961). The exact origin of the high-employment budget concept is not clear. Apparently Professor Mitton Friedman and the Committee for Economic Development first discussed budget policy in these terms at about the same time. Friedman's article however, makes a reference to Fiscal and Monetary Policy, National Planning Pamphlet No. 35 (July, 1944), by Beardsley Ruml and $H$. Chr. Sonne, which supposedly is the first to discuss budget policy in high employment terms. See Milton Friedman, "A Monetary and Fiscal Framework for Economic Stability," American Economic Review, XXXVIII (June 1948), 245-264, and Taxes and the Budget: A Program for Prosperity in a Free Economy, a statement on national policy by the Research and Policy Committee of the Conmittee for Economic Development (November, 1947).

¿See Appendix, "Analytical Use of the High-Employment Budget."

5 See Teeters, op. cit.

Page 6 
fourth quarter of $1965 .{ }^{\circ}$ This article presents estimates for the period from the first quarter of 1947 to the second quarter of 1955 , following as closely as possible the Council's procedures. ${ }^{7}$ In addition, the estimates for the period from the third quarter of 1955 to the fourth quarter of 1965 are revised to maintain consistency in the overall series and also to reflect subsequent revisions (since April 1966) in the national income accounts data. ${ }^{8}$ The estimates are also extended through the first quarter of 1967.

The Council's method of estimating the high-employment budget consists of several steps. Estimates of high-employment receipts involve the following:

(1) Defining high employment and calculating a high-employment level GNP (in money terms) consistent with it;

(2) Estimating the major relevant income components of GNP at high employment, i.e., personal income, corporate profits, and wages and salaries;

(3) Applying high-employment tax rates to the derived income components, which serve as proxies for actual tax bases.

Estimates of high-employment expenditures are quite straightforward. All expenditures, except for unemployment compensation, are considered invariant with the level of economic activity. Consequently, unemployment benefits at high employment are calculated and actual unemployment payments are ad. justed for deviations from the high-employment norm."

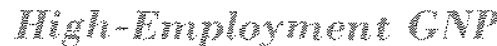

The definition of high employment is quite arbitrary. The particular choice is not crucial in the estimation of the high-employment budget for purposes

${ }^{6}$ See the Hearings on the January 1966 Economic Report of the President, p. 10 ?.

${ }^{7}$ It is believed that this is the first time that this has been done. Levy, op. cit., pp. 26, 104, 108, provides half-year estimates for 1947 to 1962 , but his procedure differs substantially from the Council's. Another set of Alternate estimates (for the period 1952:I to 1964 IV) is found in Gramlich, op. cit., pp. 137-139. Despite the difference in estimation procedure, the results presented here do not appear to differ markedly from either Levy's or Gramlich's, after subsequent revisions in the national income accounts are taken into account.

${ }^{8}$ Since it is difficult to duplicate exactly someone else's procedures, it was deemed advisable to formulate independent estimates for the 1955 to 1965 period in order to preserve comparability with estimates for earlier and later periods.

${ }^{9}$ For a fuller discussion of the problems underlying the treat* ment of unemployment insurance, see Teeters, op. cit., pp. $309-310$. of measuring fiscal actions. For this purpose, the high-employment budget standardizes the budget on some constant level of economic activity, and whether high employment is defined as 2 per cent, 4 per cent, or 6 per cent unemployment is essentially irrelevant. The general effect of varying the high-employment definition is to displace the entire series up or down without substantially altering the quarter-to-quarter or year-to-year movements in the series.

For the purpose of estimating fiscal impact, i.e., a measure of "restrictiveness" or "stimulativeness," high employment should be defined in terms of a highemployment target. The estimate of the budget at this high-employment level provides a standardized measure (i.e., abstracts from the built-in-stabilizer effects) of the net contribution of the budget to the income stream of the economy. ${ }^{10}$

To estimate high-employment receipts it is necessary to estimate a GNP figure in money terms that is consistent with the definition of high employment that is chosen. The method used by the Council is the growth rate extrapolation method, which is a simplification and smoothing of "Okun's Law."1 Implicit in this method is the assumption that real high-employment GNP grows at a constant rate over extended periods of time. Once this rate is determined, and a base year representing full-resource utilization is selected, real high-employment GNP can be calculated for the entire relevant period. This series is converted into money terms by multiplying by the implicit price deflator for GNP. ${ }^{12}$

The base period selected by the Council was mid1955; i.e., actual and high-employment GNP were assumed to be the same at that time. A 3.5 per cent growth rate was applied to this base period to derive

10 See Appendix.

11 Okun's Law relates total output to labor-force utilization and productivity. See Arthur Okun, "Potential CNP: Its Measurement and Significance," Papers and Proceedings of the Business and Economic Statistics Section of the American Statistical Association (1962), pp.98-104. A discussion of more recent research on the rate of high-employment growth is found in Lester C. Thurow and L. D. Taylor, "The Interaction Between the Actual and the Potential Rates of Growth,", Review of Economics and Statistics, XLVIII (November, 1966), 351-60.

12 This procedure biases the estimates of high-employment GNP in money terms. If the economy were at high employment, prices would certainly be changing differently than when the economy is above or below high employment. Allowing for this complication introduces difficulties in the use of the high-employment budget for planning stabllization policy. A price level assumption consistent with continuous high employment, independent of short-run deviations therefrom, seems to conflict with the very purpose of short-rur stabilization policy. 


\section{Utilization of Economic Resources}

\section{High-Employment GNP and Actual GNP in 1958 Prices}
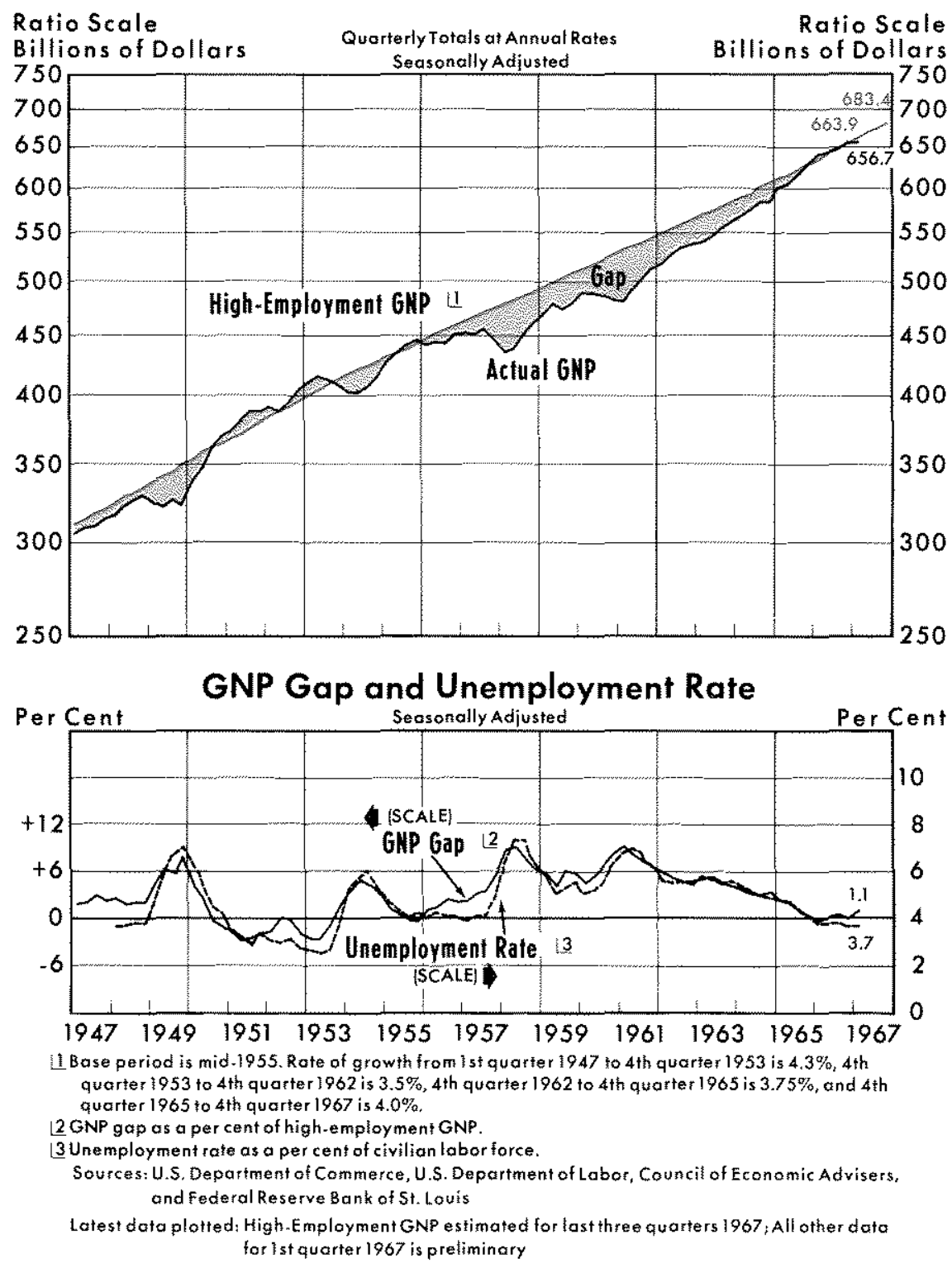

\section{Prones for Tran Thes}

Once high-employment GNP has been defined and calculated, the basis for estimating the relevant tax bases is provided. Assumptions are made about the proportions of high-employment GNP going to personal income, corporate profits, and wages and salaries.

These GNP components do not conform exactly with the way the tax bases are defined according to the tax laws. The need to use proxies is dictated by the availability of data; the national income accounts data appear to provide as reasonable a proxy as any for the major sources of tax revenue.

The particular proportions used are based on actual relationships between various income measures and GNP. High-employment points provide useful benchmarks to ascertain long-term trends in these relationships. No formal theory of income distribution is used as a foundation for their calculation. ${ }^{14}$

\section{That hes and \\ Expendintres}

Tax Rates. To calculate highemployment receipts for a particular tax requires an estimate of the tax rate in addition to the relevant income component as defined above. The general procedure for estimating the rate is to examine actual rates, (i.e. as computed

the constant dollar high-employment GNP series for 1954 through 1962. A 4.3 per cent rate of growth was applied to $1947-1953 ; 3.75$ per cent to $1962-1965$; and 4.0 per cent to 1966 and thereafter. ${ }^{13}$ Such growth rates in real output are roughly consistent with a 4 per cent level of unemployment.

\footnotetext{
13 See the January 1967 Annual Report of The Council of Economic Advisers, pp. 42-44. The 4.3 per cent estimated rate of growth for the 1947.53 period has not appeared in the Council's annual reports. However, this rate was suggested at the Hearings on the January 1961 Economic Report of the Presilent and the Economic Situation and Outlook, p. 376.
}

from the national income accounts) and in particular note those points in time when tax laws are changed. ${ }^{15}$ For those taxes that are responsive to variations in income, actual rates move with income, which makes it necessary to determine the tax rates for high-employ-

\footnotetext{
14 For a discussion of the movement of income shares in the post-World War II period, see Edwin Kuh, "Income Distribution and Employment over the Business Cycle," in J. S. Duesenberry, G. Fromm, L. R. Klein and E. Kuh (Eds.) The Brookings Ouarterly Econometric Model of the United States (Chicago: Rand McNally, 1965), pp. 228-278.

15 Such information is obtained from the various issues of the Annual Report of the Secretary of the Treasury on the State of the Finances.
} 
ment levels of activity. This consideration is especially important for personal income taxes.

Actual computed rates tend to fluctuate, even in the absence of changes in the tax laws. Such fluctuations reflect, in part, random errors in the process of computing the estimates in the national income accounts. Errors may stem from either errors in estimating receipts or errors in estimating income, which provides the basis for the tax. Additional variation in actual computed tax rates is explained by changing distribution of income in the case of personal income and corporate profits, and changing composition of expenditures for taxable items in the case of excise taxes.

Expenditures. The problem of estimating Government expenditures at high employment reduces to the determination of what unemployment benefits would be at high employment. Once this has been determined, actual benefits paid can be adjusted accordingly. The procedure used here to estimate high-employment unemployment benefits is to select such points of high activity over the 1947-1967 period and connect them with a straight line. Such benefits trended smoothly upward for the period.

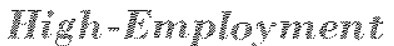 \\ Budget Entrmes}

The estimates of the high-employment budget are shown in the accompanying chart and table.

The interpretation of these data is that the difference between the national income accounts budget and the high-employment budget are caused by two factors-cyclical and random. Generally, the emphasis underlying the interpretation of the high-employment budget is that theoretically it does not reffect cyclical variations in receipts. Consequently, the high-employment budget reflects discretionary fiscal actions (changes in expend-

\section{High-Employment and Actual National Income Accounts Budget}

Quarterly Totals at Annual Rates
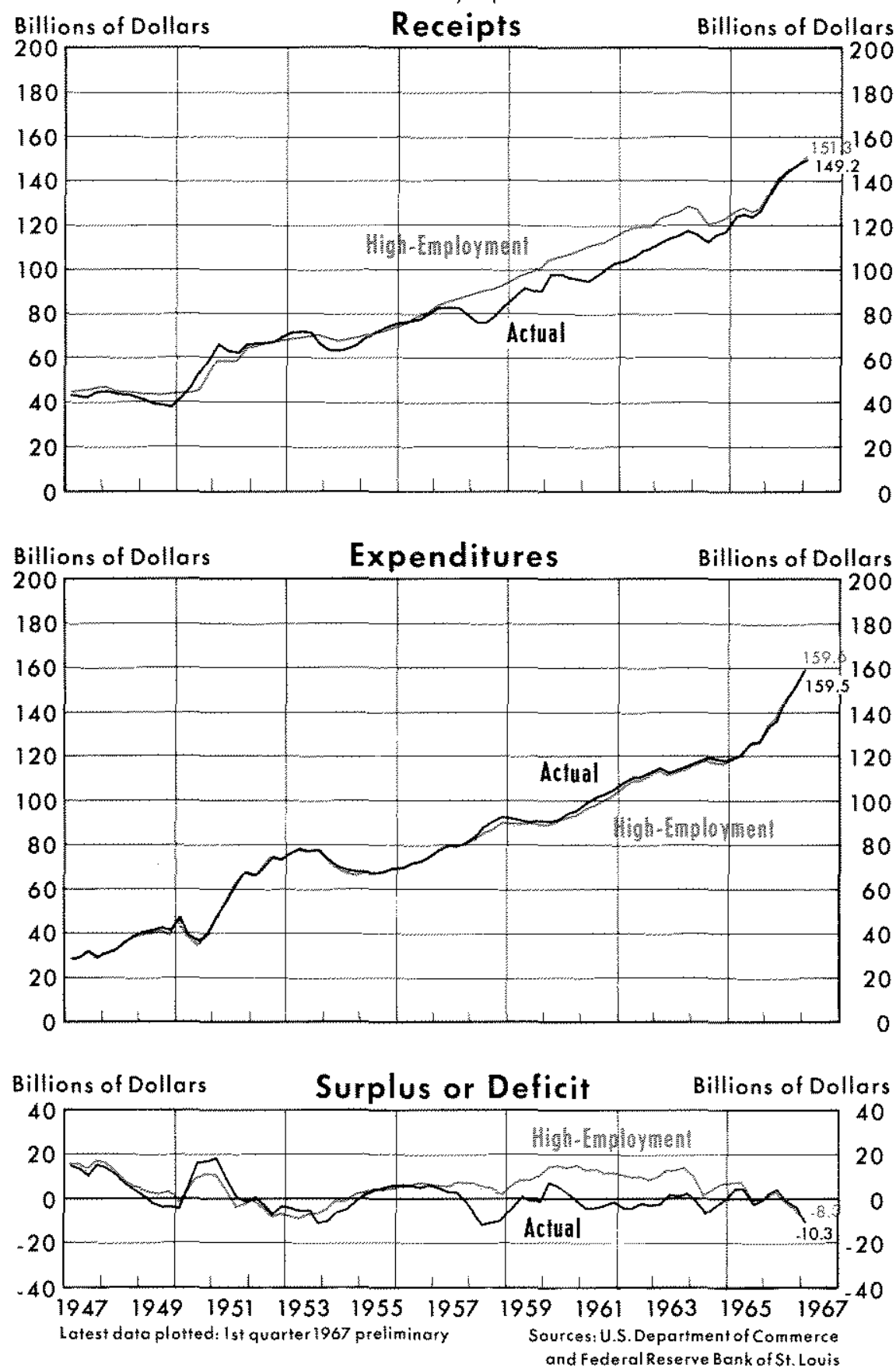

itures and changes in tax rates) and the effects of economic growth on tax receipts and on expenditures for unemployment insurance.

Hence, the high-employment budget can be expected to increase over time without changes in tax rates, provided that Government expenditures are constant. If one allows for trend growth in expenditures, 


\section{NATOMAL INCOME ACCOUNTS SUDGE}

Seasonally Adjusted Annual Rates

(Billions of Dollars)

Receipts

\begin{tabular}{|c|c|c|c|c|c|c|c|}
\hline \multirow{3}{*}{1947} & \multirow[b]{2}{*}{ Quarter } & \multicolumn{2}{|c|}{ Receipts } & \multicolumn{2}{|c|}{ Expendtrures } & \multirow{2}{*}{$\begin{array}{l}\text { Surplus } \\
\text { Actual }\end{array}$} & \multirow{2}{*}{$\frac{\text { or Deficit }}{\text { High }} \underset{\text { Employment }}{ }$} \\
\hline & & Actual & $\begin{array}{c}\text { High } \\
\text { Employment }\end{array}$ & Actual & $\begin{array}{c}\text { High } \\
\text { Employment }\end{array}$ & & \\
\hline & $\begin{array}{l}\text { I } \\
\text { II } \\
\text { II } \\
\text { IV }\end{array}$ & $\begin{array}{l}43.5 \\
42.8 \\
42.7 \\
44.5\end{array}$ & $\begin{array}{l}44.2 \\
44.6 \\
45.2 \\
46.3\end{array}$ & $\begin{array}{l}28.7 \\
29.2 \\
32.2 \\
29.3\end{array}$ & $\begin{array}{l}28.5 \\
28.9 \\
32.0 \\
29.2\end{array}$ & $\begin{array}{l}14.8 \\
13.6 \\
10.0 \\
15.2\end{array}$ & $\begin{array}{l}15.7 \\
15.7 \\
13.2 \\
17.1\end{array}$ \\
\hline 1948 & $\begin{array}{l}1 \\
11 \\
11 \\
\text { IV }\end{array}$ & $\begin{array}{l}44.7 \\
43.5 \\
42.6 \\
42.4\end{array}$ & $\begin{array}{l}46.9 \\
44.8 \\
44.2 \\
44.0 \\
\end{array}$ & $\begin{array}{l}31.0 \\
32.9 \\
36.7 \\
39.0 \\
\end{array}$ & $\begin{array}{l}30.9 \\
32.7 \\
36.6 \\
38.8\end{array}$ & $\begin{array}{r}13.7 \\
10.6 \\
5.9 \\
3.4\end{array}$ & $\begin{array}{r}16.0 \\
12.1 \\
7.6 \\
5.2\end{array}$ \\
\hline 1949 & $\begin{array}{c}1 \\
\text { II } \\
\text { III } \\
\text { IV }\end{array}$ & $\begin{array}{l}40.8 \\
38.8 \\
38.5 \\
37.5\end{array}$ & $\begin{array}{l}43.7 \\
43.5 \\
43.3 \\
43.4\end{array}$ & $\begin{array}{l}40.0 \\
41.7 \\
42.4 \\
41.4\end{array}$ & $\begin{array}{l}39.5 \\
40.7 \\
41.1 \\
39.7\end{array}$ & $\begin{array}{r}.8 \\
-2.9 \\
-\quad 3.9 \\
-3.9\end{array}$ & $\begin{array}{l}4.2 \\
2.8 \\
2.2 \\
3.7\end{array}$ \\
\hline 1950 & $\begin{array}{r}1 \\
11 \\
\text { III } \\
\text { IV }\end{array}$ & $\begin{array}{l}42.4 \\
46.6 \\
52.9 \\
57.5 \\
\end{array}$ & $\begin{array}{l}44.0 \\
44.4 \\
45.6 \\
51.5 \\
\end{array}$ & $\begin{array}{l}47.2 \\
39.0 \\
36.4 \\
40.4 \\
\end{array}$ & $\begin{array}{l}46.0 \\
38.2 \\
36.1 \\
40.4 \\
\end{array}$ & $\begin{array}{r}4.8 \\
7.6 \\
16.4 \\
17.1\end{array}$ & $\begin{array}{r}2.0 \\
6.2 \\
9.5 \\
11.1 \\
\end{array}$ \\
\hline 1951 & $\begin{array}{c}\text { I } \\
\text { II } \\
\text { III } \\
\text { IV }\end{array}$ & $\begin{array}{l}65.6 \\
62.7 \\
62.0 \\
65.9 \\
\end{array}$ & $\begin{array}{l}58.6 \\
58.3 \\
58.4 \\
64.7\end{array}$ & $\begin{array}{l}47.6 \\
54.5 \\
61.9 \\
67.2 \\
\end{array}$ & $\begin{array}{l}47.7 \\
54.7 \\
62.0 \\
67.2 \\
\end{array}$ & $\begin{array}{r}18.0 \\
8.2 \\
.1 \\
-1.3\end{array}$ & $\begin{array}{r}10.9 \\
3.6 \\
-\quad 3.6 \\
-\quad 2.5 \\
\end{array}$ \\
\hline 1952 & $\begin{array}{c}\text { I } \\
\text { II } \\
\text { II }\end{array}$ & $\begin{array}{l}66.2 \\
66.3 \\
66.8 \\
69.8 \\
\end{array}$ & $\begin{array}{l}65.1 \\
66.2 \\
67.0 \\
67.5\end{array}$ & $\begin{array}{l}66.1 \\
70.1 \\
74.4 \\
73.5\end{array}$ & $\begin{array}{l}66.1 \\
70.1 \\
74.3 \\
73.8\end{array}$ & $\begin{array}{r}.1 \\
-3.8 \\
-7.6 \\
-\quad 3.7\end{array}$ & $\begin{array}{r}-1.0 \\
-3.9 \\
-7.3 \\
-6.3\end{array}$ \\
\hline 1953 & $\begin{array}{l}\text { I } \\
\text { II } \\
\text { II }\end{array}$ & $\begin{array}{l}71.7 \\
71.9 \\
70.7 \\
65.6 \\
\end{array}$ & $\begin{array}{l}68.3 \\
68.9 \\
69.5 \\
70.4 \\
\end{array}$ & $\begin{array}{l}76.2 \\
78.0 \\
76.5 \\
77.3 \\
\end{array}$ & $\begin{array}{l}76.4 \\
78.3 \\
76.8 \\
77.2 \\
\end{array}$ & $\begin{array}{r}4.5 \\
-6.2 \\
-5.7 \\
-11.7\end{array}$ & $\begin{array}{r}-8.1 \\
-9.4 \\
-7.3 \\
-6.8 \\
\end{array}$ \\
\hline 1954 & $\begin{array}{r}1 \\
11 \\
111 \\
14\end{array}$ & $\begin{array}{l}62.9 \\
62.9 \\
63.6 \\
65.7\end{array}$ & $\begin{array}{l}68.3 \\
67.9 \\
68.3 \\
69.4 \\
\end{array}$ & $\begin{array}{l}73.4 \\
69.5 \\
68.6 \\
67.6 \\
\end{array}$ & $\begin{array}{l}72.8 \\
68.5 \\
67.6 \\
66.7 \\
\end{array}$ & $\begin{array}{r}-10.5 \\
-6.6 \\
-\quad 5.0 \\
-1.8\end{array}$ & $\begin{array}{r}4.5 \\
-6 \\
.7 \\
2.7 \\
\end{array}$ \\
\hline 1955 & $\begin{array}{l}\text { I } \\
\text { II } \\
\text { III }\end{array}$ & $\begin{array}{l}69.2 \\
71.1 \\
73.3 \\
75.0 \\
\end{array}$ & $\begin{array}{l}70.2 \\
71.5 \\
72.4 \\
73.8 \\
\end{array}$ & $\begin{array}{l}67.9 \\
67.1 \\
68.3 \\
69.0 \\
\end{array}$ & $\begin{array}{l}67.6 \\
67.1 \\
68.4 \\
69.1 \\
\end{array}$ & $\begin{array}{l}1.3 \\
4.0 \\
5.0 \\
6.0\end{array}$ & $\begin{array}{l}2.6 \\
4.4 \\
4.0 \\
4.7\end{array}$ \\
\hline 1956 & $\begin{array}{l}\text { I } \\
\text { II } \\
\text { If } \\
\text { IV }\end{array}$ & $\begin{array}{l}75.6 \\
77.2 \\
77.2 \\
80.1\end{array}$ & $\begin{array}{l}75.7 \\
77.3 \\
79.0 \\
80.6 \\
\end{array}$ & $\begin{array}{l}69.3 \\
71.8 \\
72.3 \\
74.1\end{array}$ & $\begin{array}{l}69.3 \\
71.8 \\
72.2 \\
74.0 \\
\end{array}$ & $\begin{array}{l}6.3 \\
5.5 \\
4.9 \\
6.0\end{array}$ & $\begin{array}{l}6.4 \\
5.5 \\
6.8 \\
6.6\end{array}$ \\
\hline 1957 & $\begin{array}{l}\text { I } \\
11 \\
\text { II } \\
\text { IV }\end{array}$ & $\begin{array}{l}82.4 \\
82.2 \\
82.3 \\
79.4 \\
\end{array}$ & $\begin{array}{l}83.6 \\
85.3 \\
86.6 \\
87.9 \\
\end{array}$ & $\begin{array}{l}78.1 \\
79.7 \\
79.7 \\
80.9 \\
\end{array}$ & $\begin{array}{l}77.9 \\
79.5 \\
79.4 \\
80.9 \\
\end{array}$ & $\begin{array}{r}4.3 \\
2.5 \\
2.6 \\
-1.5 \\
\end{array}$ & $\begin{array}{l}5.7 \\
5.8 \\
7.2 \\
7.0 \\
\end{array}$ \\
\hline 1958 & $\begin{array}{r}1 \\
11 \\
111 \\
\text { IV }\end{array}$ & $\begin{array}{l}76.0 \\
75.9 \\
79.5 \\
83.1 \\
\end{array}$ & $\begin{array}{l}89.1 \\
90.5 \\
91.4 \\
93.0\end{array}$ & $\begin{array}{l}84.1 \\
88.3 \\
90.3 \\
92.9\end{array}$ & $\begin{array}{l}82.4 \\
85.4 \\
87.1 \\
90.6\end{array}$ & $\begin{array}{r}-8.1 \\
-12.4 \\
-10.8 \\
-9.8\end{array}$ & $\begin{array}{l}6.7 \\
5.1 \\
4.3 \\
2.4\end{array}$ \\
\hline 1959 & $\begin{array}{l}1 \\
11 \\
\text { III }\end{array}$ & $\begin{array}{l}87.5 \\
91.2 \\
89.9 \\
90.3 \\
\end{array}$ & $\begin{array}{r}96.2 \\
97.8 \\
99.0 \\
100.3 \\
\end{array}$ & $\begin{array}{l}91.7 \\
90.4 \\
90.9 \\
91.0\end{array}$ & $\begin{array}{l}90.2 \\
89.7 \\
90.3 \\
89.8\end{array}$ & $\begin{array}{r}4.2 \\
.8 \\
-1.0 \\
-6\end{array}$ & $\begin{array}{r}6.0 \\
8.1 \\
8.7 \\
10.5\end{array}$ \\
\hline 1960 & $\begin{array}{c}1 \\
11 \\
\text { III } \\
\text { IV }\end{array}$ & $\begin{array}{l}97.5 \\
97.6 \\
95.7 \\
95.1\end{array}$ & $\begin{array}{l}104.7 \\
106.0 \\
106.9 \\
108.8\end{array}$ & $\begin{array}{l}90.4 \\
92.0 \\
94.2 \\
95.7\end{array}$ & $\begin{array}{l}89.5 \\
91.0 \\
92.7 \\
93.7\end{array}$ & $\begin{array}{r}7.1 \\
5.6 \\
1.5 \\
-\quad .6\end{array}$ & $\begin{array}{l}14.6 \\
15.0 \\
14.2 \\
15.1\end{array}$ \\
\hline 1961 & $\begin{array}{l}\text { I } \\
\text { II } \\
\text { III } \\
\text { IV }\end{array}$ & $\begin{array}{r}94.4 \\
97.1 \\
99.1 \\
102.4\end{array}$ & $\begin{array}{l}110.2 \\
111.8 \\
112.4 \\
114.5\end{array}$ & $\begin{array}{r}99.3 \\
101.6 \\
102.9 \\
104.3\end{array}$ & $\begin{array}{r}97.1 \\
98.5 \\
100.5 \\
102.4\end{array}$ & $\begin{array}{r}-4.9 \\
-4.5 \\
-\quad 3.8 \\
-\quad 1.9\end{array}$ & $\begin{array}{l}13.1 \\
13.3 \\
11.9 \\
12.1\end{array}$ \\
\hline
\end{tabular}

Expenditures

High

Actual Employment

29.2

Page 10 


\begin{tabular}{|c|c|c|c|c|c|c|c|}
\hline \multirow{3}{*}{1962} & \multirow[b]{2}{*}{ Quarter } & \multicolumn{2}{|c|}{ Receipts } & \multicolumn{2}{|c|}{ Expenditures } & \multirow{2}{*}{$\begin{array}{l}\text { Surplus } \\
\text { Actual }\end{array}$} & \multirow{2}{*}{$\frac{\text { or Defict }}{\text { High }}$} \\
\hline & & Actual & $\begin{array}{c}\text { High } \\
\text { Employment }\end{array}$ & Actual & $\begin{array}{l}\text { High } \\
\text { Employment }\end{array}$ & & \\
\hline & $\begin{array}{c}1 \\
\text { II } \\
\text { III } \\
\text { IV }\end{array}$ & $\begin{array}{l}103.4 \\
105.6 \\
107.6 \\
109.2\end{array}$ & $\begin{array}{l}117.7 \\
119.1 \\
119.2 \\
119.6\end{array}$ & $\begin{array}{l}108.4 \\
110.2 \\
110.2 \\
112.4\end{array}$ & $\begin{array}{l}106.8 \\
109.2 \\
109.2 \\
111.3\end{array}$ & $\begin{array}{r}-5.0 \\
-4.5 \\
-\quad 2.6 \\
-3.2\end{array}$ & $\begin{array}{r}10.9 \\
9.9 \\
10.0 \\
8.3\end{array}$ \\
\hline 1963 & $\begin{array}{l}\text { I } \\
\text { II } \\
\text { III } \\
\text { IV }\end{array}$ & $\begin{array}{l}112.0 \\
113.9 \\
115.0 \\
117.2\end{array}$ & $\begin{array}{l}123.3 \\
124.8 \\
126.2 \\
128.6\end{array}$ & $\begin{array}{l}114.4 \\
112.1 \\
113.8 \\
115.1 \\
\end{array}$ & $\begin{array}{l}113.2 \\
111.1 \\
112.9 \\
114.3\end{array}$ & $\begin{array}{r}2.4 \\
1.8 \\
1.2 \\
2.1\end{array}$ & $\begin{array}{l}10.1 \\
13.7 \\
13.3 \\
14.3\end{array}$ \\
\hline 1964 & $\begin{array}{l}1 \\
\text { II } \\
\text { III } \\
\text { IV }\end{array}$ & $\begin{array}{l}115.3 \\
112.3 \\
115.4 \\
117.2\end{array}$ & $\begin{array}{l}127.0 \\
120.4 \\
121.8 \\
124.0\end{array}$ & $\begin{array}{l}117.2 \\
119.1 \\
118.4 \\
117.7\end{array}$ & $\begin{array}{l}116.4 \\
118.4 \\
117.8 \\
117.2\end{array}$ & $\begin{array}{r}1.9 \\
-\quad 6.7 \\
-\quad 3.0 \\
-\quad .5\end{array}$ & $\begin{array}{r}10.6 \\
2.0 \\
4.0 \\
6.8\end{array}$ \\
\hline 1965 & $\begin{array}{c}1 \\
11 \\
\text { III } \\
\text { IV }\end{array}$ & $\begin{array}{l}124.0 \\
125.0 \\
123.8 \\
126.9\end{array}$ & $\begin{array}{l}126.4 \\
127.8 \\
125.9 \\
127.6\end{array}$ & $\begin{array}{l}119.6 \\
120.6 \\
126.3 \\
127.0\end{array}$ & $\begin{array}{l}119.1 \\
120.4 \\
126.1 \\
127.0\end{array}$ & $\begin{array}{r}4.5 \\
4.4 \\
-\quad 2.5 \\
-\quad .2\end{array}$ & $\begin{array}{r}7.3 \\
7.4 \\
-\quad .2 \\
.6\end{array}$ \\
\hline 1966 & $\begin{array}{c}1 \\
\text { H } \\
\text { II } \\
\text { IV }\end{array}$ & $\begin{array}{l}136.0 \\
141.0 \\
145.3 \\
147.9\end{array}$ & $\begin{array}{l}134.9 \\
141.1 \\
145.7 \\
148.0\end{array}$ & $\begin{array}{l}133.7 \\
137.1 \\
145.8 \\
151.5\end{array}$ & $\begin{array}{l}133.8 \\
137.6 \\
146.1 \\
151.9\end{array}$ & $\begin{array}{r}2.3 \\
3.8 \\
-\quad .5 \\
-\quad 3.6\end{array}$ & $\begin{array}{r}1.1 \\
3.5 \\
-\quad .4 \\
-\quad 3.9\end{array}$ \\
\hline 1967 & $\begin{array}{l}\text { IP } \\
\text { III } \\
\text { IV }\end{array}$ & 149.2 & 151,3 & 159.5 & 159.6 & -10.3 & -8.3 \\
\hline
\end{tabular}

p- preliminary

Sources; U.S. Department of Commerce and Federal Reserve Bank of St. Louis.

say at the same rate as high-employment GNP, the net of receipts and expenditures comes close to reflecting changes in tax rates and/or changes in government expenditures above or below trend growth. ${ }^{16}$

An examination of the chart showing surpluses or deficits in the high-employment budget indicates that the 20-year period 1947-1966 can be divided into three subperiods. The period from 1947-1954 was one of frequent changes in tax rates and frequent changes in the rate of growth in Government expenditures. Most of the variation in the high-employment budget during that period reflects war or the aftermath of war. Personal income taxes were reduced in 1948, and vir-

\footnotetext{
16 Even with such an assumption of trend growth in expenditure, the high-employment budget will tend to increase without tax rate changes. With a progressive tax structure, trend growth in receipts exceeds the rate of growth in high employment GNP. For an extensive discussion of these effects, along with quantitative measures, see Levy, op, cit, pp. 85-88. This point provided the basis for a speech by fames Duesenbery, a member of the Council of Economic $\mathrm{Ad}$ visers, before the National Machine Tool Builders Association on May 12,1967 .

"When government expenditures rise by more than the normal growth of full employment revenues, we ought to raise taxes, unless the economy is operating below full employment or private demand shows weakness.

"Conversely, when government expenditures grow by less than the normal growth of full employment revenues, we ought to reduce taxes unless demand is already excessively strong or private demand is growing unusually fast."
}

tually all taxes were raised in 1950 and again in 1951. The years 1953 and 1954 saw the expiration of the excess profits tax and a reduction in personal income taxes.

The period from 1955-1962 was marked almost solely by variations in expenditures rather than by changing tax rates. Expenditures varied widely over the period while the structure of corporate and personal income tax rates was essentially unchanged. There were periodic changes in social security taxes and occasional changes in excise tax rates, but their magnitudes were relatively small.

The most recent period, 1962-1966, marked a resumption of active and frequent changes in tax policy. The investment tax credit, along with a revised and liberalized schedule of depreciation allowances, was introduced in 1962. The personal and corporate income tax reduction in 1964 was followed by a reduction in excise taxes in mid-1965. An additional tax action was taken in September of 1966 when the provisions of the Revenue Act of 1962 were temporarily rescinded.

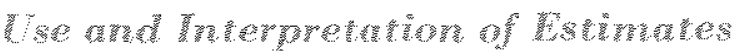

Measure of Fiscal Action. One interpretation of the high-employment budget is that it serves as a measure 


\section{High-Employment Budget Surplus or Deficit as a Per Cent of High-Employment GNP}

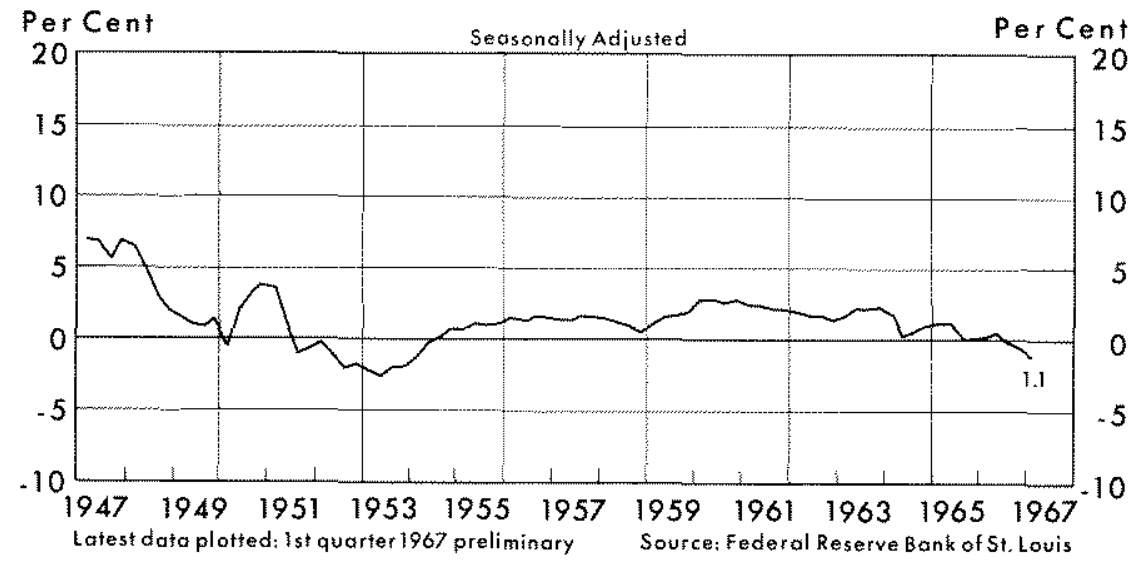

mind that the economy is growing. Thus the impact of a $\$ 10$ billion surplus has a greater impact on a $\$ 500$ billion economy than on a $\$ 700$ billion economy. Thus the relative high-employment budget, i. e, the surplus or deficit expressed as a per cent of high-employment GNP, might be more meaningful as a measure of economic impact. ${ }^{18}$ This measure might provide a partial explanation of the slowdown in economic activity in early 1967 in the face of stimulative (by historical standards) budget developments in late 1966 and early 1967 . The relative of discretionary fiscal action. Such an interpretation is not precisely correct because of the upward trend in tax receipts as the economy grows over time. If a trend assumption is made with regard to expenditures, this interpretation tends to be more valid. $A$ change in the high-employment surplus or deficit from one quarter to the next is an approximate measure of the extent that fiscal actions have tended to more than compensate, or less than compensate, as the case may be, for the trend effect of both expenditures and receipts.

Measure of Fiscal Impact. Another use of the high-employment budget, aside from a measure of fiscal action, is to interpret the surplus or deficit as a variable to be manipulated to achieve high employment. ${ }^{17}$ A surplus in this budget, for example, indicates that private investment plans must exceed private saving plans by that amount in order for high employment to be realized; if the discrepancy between high-employment investment and saving differs from that amount, the surplus must be altered accordingly to achieve high employment.

In this way the high-employment budget serves as a powerful tool of economic analysis that assists in the planning of appropriate monetary or fiscal action so as to achieve high employment with relatively stable prices. The process however, involves difficult problems in estimating what planned private saving and investment would be at some target level of high employment, as well as allowing for time lags in the effect of monetary and fiscal actions.

When considering the impact of the budget on the economy over the years, it is important to keep in

${ }^{17}$ See Appendix. high-employment budget is charted above.

Pitfalls in Usage. One of the problems in interpreting the high employment budget is the extent to which small changes in the surplus or deficit can be taken seriously. The calculation is relatively crude and approximate with several underlying assumptions.

The level of the surplus or deficit is, therefore, of questionable reliability. The level depends on the particular choice of the definition of high employment. Furthermore, the estimates of high-employment values of the relevant income components and tax rates are imperfect. Changes in the surplus or deficit, however, might be considered as approximate indicators of the direction in which budget actions are moving. ${ }^{19}$

In the assessment of the economic impact of the budget, the composition of expenditures and the structure of taxes are also relevant. Consequently, little or no change in the surplus or deficit is ambiguous and does not necessarily imply no change in fiscal actions or impact if the composition of expenditures and/or the structure of taxes has changed significantly. ${ }^{20}$

18 See Levy, op. cit., pp. 87.88.

19 No specific guidelines can be offered, but modest changes in the surplus or deficit should not be considered significant.

20In the same vein, it should also be pointed out that the high-employment budget as calculated here, makes no allowance for the so-called "balanced budget multiplier." According to this theory a dollar of increased expenditure has a greater economic effect than a dollar decline in tax receipts (because taxes tend to come out of saving as well as consumption). Thus an equal increase in both expenditures and receipts (no change in the surplus or deficit) will still have a positive economic impact. For an attempt to allow for such effects (calculating a weighted high-employment budget), see Gramlich, op. cit. See also R. A. Musgrave, "On Measuring Fiscal Performance," Review of Economics and Statistics, XLVI (May, 1964), 213-20. 
The high-employment budget is not meant to be a substitute for more conventional budget concepts. Rather, it should be used in conjunction with other budgets, and be considered simply as an addition to the kit of tools that economic analysts can use in the interpretation and understanding of economic events and policy actions."

21 With a view toward promoting a better understanding of the Federal budget, a Presidential Commission has recently been formed to review traditional budgetary concepts and recommend changes in the way the budget is presented to the public.

Ketth CarLSON

\section{APPENDIX}

\section{Analytical Use of the High-Employment Budget ${ }^{2}$}

The usefulness of the high-employment budget in the analysis of economic stabilization policies can be demonstrated with the modern theory of the determination of the level of economic activity.

According to economic theory, the level of economic activity is determined by the saving and spending propensities of households, businesses, governments, and foreign ers. ${ }^{2}$ The most comprehensive measure of economic activity is gross national product (GNP) - the total value of final goods and services produced in a given time period. GNP can be measured by summing all expenditures or by sum ming all incomes. All production can be thought of as being bought; thus, the total product can be measured by gross national expenditure (GNE) on this product. Similarly, all production has income charges against it equal in value to what is produced; thus the total product can be measured by gross national income (GNY). This definitional relationship between total product, total expenditure, and total income can be expressed as follows (where triple bar, $\equiv$, means "identically equals"):

\section{(1) $\mathrm{GNP} \equiv \mathrm{GNE} \equiv \mathrm{GNY}$}

Gross national expenditure (GNE) can be divided into its major components - consumption (C), investment (I), and government purchases (G). Gross national income (GNY) must be allocated to consumption (C), saving (S), and taxes (T). Equation (1) can be rewritten,

\footnotetext{
1This appendix is essentially the same as the analytical framework summarized in the April 1966 issue of this Review, pp. 9-11. This, in turn, was based primarily on Solomon, op. cit.

${ }^{2}$ All terms are defined so as to be roughly consistent with the national income accounts framework. Investment is defined to include gross private domestic investment and net foreign investment; private saving includes personal and business saving, and state and local government saving; government purchases are for the Federal Government; and net Federal Govermment receipts are essentially taxes net of transfer payments.
}

expressing GNE and GNY as the sum of their components:

(2) $\mathrm{C}+\mathrm{I}+\mathrm{G}=\mathrm{C}+\mathrm{S}+\mathrm{T}$

where $\mathrm{C}=$ personal consumption expenditures;

$1=$ gross private investment;

$G=$ govermment purchases of goods and services;

$\mathrm{S}=$ gross private saving;

$\mathrm{T}=$ net government receipts.

Both GNE and GNY contain consumption (C). As a part of GNE, consumption is spending on consumer goods and services. As an allocation of GNY, consumption is that portion of income spent on consumer goods and services. Both statements refer to the same magnitude. For convenience, consumption (C) can be ignored, and attention focused on the remainder of $\mathrm{GNE}$, i.e., $(I+\mathrm{G})$, and the remainder of GNY, i.e., $(S+T)$. Dropping con" sumption (C) from both sides of equation (2) leaves:

$$
\text { (3) } \mathrm{I}+\mathrm{G} \equiv \mathrm{S}+\mathrm{T} \text {. }
$$

Government expenditures (G) can be netted against receipts (T), yielding government saving ( $\mathrm{T}-\mathrm{G}$ ), the Federal budget surplus or deficit. The result of such a rearrangement shows that investment (I) is identically equal to total saving $\mathrm{S}+(\mathrm{T}-\mathrm{G})$ :

(4) $\mathrm{I} \equiv \mathrm{S}+(\mathrm{T}-\mathrm{G})$

In an accounting sense, saving and investment are always equal, regardless of the level of GNP. However, accounting definitions of saving and investment do not themselves provide an explanation of the dynamic forces that cause GNP to be what it is. Nevertheless, the concepts are useful in developing a framework for understanding what determines GNP.

Although measured saving and investment are always equal, planned saving and investment are not. Saving and investment are performed largely by different groups; each group is motivated by its own set of considerations. An attempt by businesses to invest more than is willingly saved by households, businesses, and governments sets 
in motion forces causing GNP to increase. Under such circumstances injections of investment expenditures into the income-expenditure stream exceed the leakages of private and government saving from it. An excess of injections over leakages leads to an increase in GNP. The rise in GNP continues to a level where planned saving and investment are brought into balance.

Whether an economy achieves high employment with stable prices (i.e., an optimal GNP) ${ }^{3}$ depends on the relation between planned saving and investment at that specified target level of economic activity. If investment falls short of planned saving at high employment, GNP will fall short of its optimal level and unemployment will result. On the other hand, if planned investment exceeds planned saving at high employment, GNP will exceed its optimal level and prices will rise. In terms of equation (4) these conclusions may be summarized as follows (where the subscript $H$ denotes "high-employment value"):

Relation between planned saving and investment

at high employment Result

$I_{\mathrm{y}}$ less than $\mathrm{S}_{\mathrm{H}}+\left(\mathrm{T}_{\mathrm{H}}-\mathrm{G}_{\mathrm{H}}\right)$

GNP falls short of its optimal level

$I_{H}$ equals $S_{H}+\left(T_{H}-G_{H}\right)$

GNP achieves its optimal level

$\mathrm{I}_{\mathrm{H}}$ greater than $\mathrm{S}_{\mathrm{II}}+\left(\mathrm{T}_{\mathrm{H}}-\mathrm{G}_{\mathrm{H}}\right) \quad \mathrm{GNP}$ exceeds its optimal level

3 This discussion ignores possible inconsistencies between high employment and stable prices. Choice of an optimal GNP probably involves a "trade off" between an increase in employment and a rise in the general level of prices.
Understanding why GNP exceeds or falls short of its optimal level is crucial to the policy formulation process. Within the analytical framework discussed here, the problem reduces to an analysis of the discrepancy between high-employment values of saving and investment. If a discrepancy exists, policy measures can be instituted which will restore GNP to its optimal level.

In particular, (1) the appropriate magnitude of the high-employment budget $\left(\mathrm{T}_{\mathrm{H}}{ } \mathrm{G}_{\mathrm{H}}\right)$ needed to achieve optimal GNP, given the relation between planned high employment values of private saving, i.e., $\left(\mathrm{I}_{\mathrm{H}}-\mathrm{S}_{\mathrm{H}}\right)$, may be stated, or (2) the amount of investment needed to close the highmemployment saving-investment gap $\left(\mathrm{I}_{\mathrm{H}} \mathrm{S}_{\mathrm{FI}}\right)$, given the magnitude of the high-employment budget $\left(\mathrm{T}_{\mathrm{H}}-\mathrm{G}_{1 \mathrm{l}}\right)$, may be specified. The first interpretation indicates the fiscal actions required to achieve optimal GNP, given monetury actions; the latter specifies the required monetary actions as they influence investment, given fiscal actions.

These interpretations of the saving-investment framework can be summarized as follows:

$$
\text { (5) } \mathrm{I}_{\mathrm{H}^{-}}-\mathrm{S}_{\mathrm{H}}=\mathrm{T}_{\mathrm{II}} \mathrm{G}_{\mathrm{HI}} \text {. }
$$

The left-hand side of equation (5) indicates the private sector of the economy, the right-hand side, the government sector. The larger is the high-employment budget surplus, $\left(T_{1 \mathrm{H}}-\mathrm{G}_{\mathrm{H}}\right)$, the more investment $\left(\mathrm{I}_{\mathrm{H}}\right)$ must exceed saving $\left(S_{H}\right)$ if high employment with stable prices is to be achieved. Alternatively, the more investment $\left(I_{11}\right)$ exceeds saving $\left(S_{3}\right)$, the larger must be the high-employment budget surplus, $\left(\mathrm{T}_{\mathrm{H}}-\mathrm{G}_{\mathrm{H}}\right)$, if optimal GNP is to be achieved.

Subsequent revisions and current estimates of the high-employment budget will be provided in this Bank's quarterly release, "Federal Budget Trends." Also available is an appendix to this article which describes in detail the assumptions that underlie the estimates presented here. These items are available on request from the Research Department, Federal Reserve Bank of St. Lonis, P.O. Box 442, St. Louis, Missouri 63166. 